\title{
Akut Kolesistit ile Başvuran Atipik Bruselloz Olgusu
}

\author{
Atypical Brucellosis Case Presenting with Acute Cholecystitis
}

\section{Sevil Alkan Çeviker ${ }^{1}$, Habibe Tülin Elmaslar Mert ${ }^{2}$, Mehmet Ali Gedik ${ }^{3}$}

${ }^{1}$ Kütahya Sağlık Bilimleri Üniversitesi, Evliya Çelebi Eğitim Araştırma Hast., Enfeksiyon Hast. ve Klinik Mikrobiyoloji Bölümü, Kütahya

${ }^{2}$ Trakya Üniversitesi Tip Fakültesi Enfeksiyon Hast. ve Klinik Mikrobiyoloji Anabilim Dal, Edirne

${ }^{3}$ Kütahya Sağlık Bilimleri Üniversitesi, Evliya Çelebi Eğitim Araştırma Hast. Radyoloji, Kütahya

\section{Yazışma Adresi / Correspondence:}

Sevil Alkan Çeviker

Kütahya Sağlık Bilimleri Üniversitesi, Evliya Çelebi Eğitim Araștırma Hastanesi, Enfeksiyon Hastalıkları ve Klinik Mikrobiyoloji Bölümü, Kütahya

$$
\text { T: +905066873768 E-mail: s-ewil@hotmail.com }
$$

Geliş Tarihi / Received : 13.05.2019 Kabul Tarihi / Accepted : 27.11.2019

Orcid:

Sevil Alkan Çeviker https://orcid.org/0000-0003-1944-2477

Habibe Tülin Elmaslar Mert https://orcid.org/0000-0002-3421-7860

Mehmet Ali Gedik https://orcid.org/0000-0002-1548-0444

( Sakarya Tip Dergisi / Sakarya Med J 2019, 9(4):702-705) DOI: 10.31832/smj.564795

XX. TÜRK KLINIIK MİKROBIYOLOJİ VE İNFEKSIYON HASTALIKLARI KONGRESİ (KLIMIIK Uluslar arası Kongresi) , 13 -16 MART 2019, , Antalya'da poster sunum olarak sunulmuștur.

Öz

Ülkemizde endemik zoonotik hastalık olan bruselloz çeșitli klinik tablolar ve komplikasyonlarla karşımıza çkabildiğinden tanı ve tedavisinde zorluk yașanabilen bir hastalıktır. Bakteriyemi yapabilme özelliği nedeniyle Brucella cinsine ait bakteriler çok çeşitli organlara yerleşip atipik klinik formlarda karşımıza çıkabilir. Brucella türlerinin neden olduğu kolesistit nadir görülen bir tablodur.Bu olgu sunumunda tanısında oldukça zorlanılan, tanısı dren kültüründe Brusella melitensis üremesi ile konulan seronegatif bruselloza bağlı akut kolesistit olgusu sunuldu. Akut kolesistit ön tanısı ile opere edilen postoperatif dönemde ateș yüksekliği ve lökopeni gelișen hastada, negatif Brusella serolojisine rağmen kan kültüründe ve dren kültüründe Brucella melitensis tespit edilmiştir. Hasta 6 haftalık doksisiklin 2x100 mg/gün ve rifampisin 1x600 mg/gün tedavisi sonrası sekelsiz iyileșmiștir.

Anahtar Bruselloz; Akut Kolesistit; seronegatif Bruselloz; Brucella melitensis. Because of its ability to make bacteremia, bacteria of the genus Brucella can be placed in wide organs and can be seen in atypical clinical forms. Cholecystitis caused by Brucella species is a rare condition. In this article, we present a case of acute cholecystitis related to seronegative brucellosis with Brucella melitensisdespite negative Brucella serology, Brusella melitensisdetected in blood and drain cultures of the patient who operated with the preliminary diagnosis of acute cholecystitis, developed fever and leukopeniain the postoperative period. The patient recovered without sequelae after 6 weeks of doxycycline $2 \times 100 \mathrm{mg} /$ day and rifampicin $1 \times 600 \mathrm{mg} /$ day treatment. 


\section{GIIRIŞ}

Ülkemizde endemik hastalık olan bruselloz, çeşitli klinik tablolar ve komplikasyonlarla karşımıza çıkabildiğinden $\tan$ ve tedavisinde zorluk yaşanabilen bir zoonotik hastalıktır. Bakteriyemi yapabilme özelliği nedeniyle Brucella cinsi bakteriler çeşitli organlara yerleşip atipik klinik formlara neden olabilir. ${ }^{1}$

Gastrointestinal sistem, bruselloz olgularında $\% 70$ ve üzeri oranda tutulur. ${ }^{2}$ Bruselloz sırasında çok çeşitli gastrointestinal belirtiler ortaya çıkabilir. Bunlar anoreksi, kusma, ishal, kabızlık gibi daha hafif şikayetlerden, mezenterik lenfadenit gibi daha ciddi komplikasyonlara kadar uzanmaktadır. Karaciğer veya dalak tutulumu (her iki organdan birinde hepatit veya granülom ve/veya apse oluşumu) ve kolesistit, kolit, pankreatit, peritonit ve ileus gibi hayat1 tehdit eden nadir komplikasyonlara neden olabilir. ${ }^{3}$ Brucella türlerinin neden olduğu kolesistit oldukça nadir görülen bir tablodur. ${ }^{4}$

$\mathrm{Bu}$ olgu sunumunda, tanısında oldukça zorlanılan, tanısı dren kültüründe Brusella melitensis üremesi ile konulan seronegatif bruselloza bağlı akut kolesistit olgusu sunuldu.

\section{OLGU SUNUMU}

Genel cerrahi kliniğine, akut kolesistit ön tanısı ile yat1rılan 30 yaşında erkek hasta postoperatif birinci günde ateş yüksekliği olması üzerine tarafımıza konsülte edildi. Hastanın öyküsünden üç gündür halsizlik ve sağ üst kadran ağrısı şikayeti olduğu öğrenildi. Kırsal kesimde yaşayan hastanın özgeçmişinde bilinen kronik hastalığ mevcut değildi. Hastanın fizik muayenesinde bilinci açık, kooperasyon veoryantasyonu tam, takipneik görünümde, nabız 110/dk, tansiyon arteryal 100/60 $\mathrm{mmHg}$, vücut 1sıs1 $38.5^{\circ} \mathrm{C}$, sağ üst kadranda operasyon lojuna uyan bölgede hassasiyeti, batında dreni mevcuttu. Diğer sistem muayeneleri olağandı. Laboratuvar tetkiklerinde lökopeni (lökosit: 3400 (\%48 nötrofil), anemi (hemoglobin:10,1g/dl), platelet:152.000/mm3, alanin amino transferaz (ALT):100 IU/L,aspartat amino transferaz (AST):60 IU/L,alkalen fos- fataz (ALP):140 U/L,gama-glutamil transferaz (GGT):138 $\mathrm{U} / \mathrm{L}$, total serum bilirübin:2.4 mg/dl, albümin:2.1 g/dl, C-reaktif protein (CRP):237mg/l, prokalsitonin $17 \mathrm{ng} / \mathrm{mL}$ olarak saptandı. Diğer biyokimyasal tetkiklerde anormal bulgu saptanmadı. Ayrıca karaciğger enzim yüksekliği nedeniyle istenen viral enfeksiyon belirteçleri (hepatit A,B,C, Citomegalovirüs) negatif olarak saptandı. Periferik yaymasında atipik hücreye rastlanmadı. Batın tomografisinde safra kesesi duvar kalınlığı artmış ve ödemli olup akut kolesistitle uyumlu olarak saptandı (Resim 1). Hastadan kan ve idrar kültürleri istendi. Ampirik olarak batın içi enfeksiyon ön tanısıyla seftriakson $2 \times 1$ gr /IV+ornidazol 2x500gr /IV tedavileri başlandi. Kültür sonuçları ile rekonsültasyon önerildi. Hastanın lökopenisinin derinleşmesi ve ateş yanıtının alınmaması üzerinetekrar konsülte edildi. Hastadan Rose Bengal ve Coombs'lu Wright tetkikleri istendi. Kan kültürü tekrarlandı. Rose Bengal testi pozitifti; Coombs'lu Wright testi 1/80 titrede pozitif olarak saptand. Hastaya klinik ve laboratuvar bulgularla bruselloz tanısı konulamadı. Hasta alınan dren kültüründe Brusella spp. üremesi üzerine tekrar konsülte edildi. Üreyen mikroorganizmaların identifikasyonu hastanemiz mikrobiyoloji laboratuvarında VITEK 2 Compact (Biomerieux clinical diagnostics, France) cihazı ile yapıldı. Brucella spp. olarak tanımlanan mikroorganizma, T.C. Sağlık Bakanlığı Halk Sağlığı Genel Müdürlüğü Mikrobiyoloji Referans Laboratuvarı’nda B.melitensis olarak tiplendirildi. Bunun üzerine hasta seronegatif bruselloza bağlı akut kolesistit olarak değerlendirildi. Hasta servisimize devir alındı. Hastanın tedavisi doksisiklin 2x100 mg/gün ve rifampisin 1x600 mg/gün olarak düzenlendi. Hastadan 2 hafta sonra tekrar Coombs'lu Wright tetkiki istendi. Coombs'lu Wright testi titresinde değişiklik olmadı.

Hastanın kan kültürlerinde de Brusella melitensis üremesi oldu. Klinik bulguları stabilleşen, dreni çekilen hastanın doksisiklin ve rifampisin kombinasyon tedavisi poliklinik kontrolleri ile altı haftaya tamamlandı. Poliklinik takiplerinde problem yaşanmadi. 


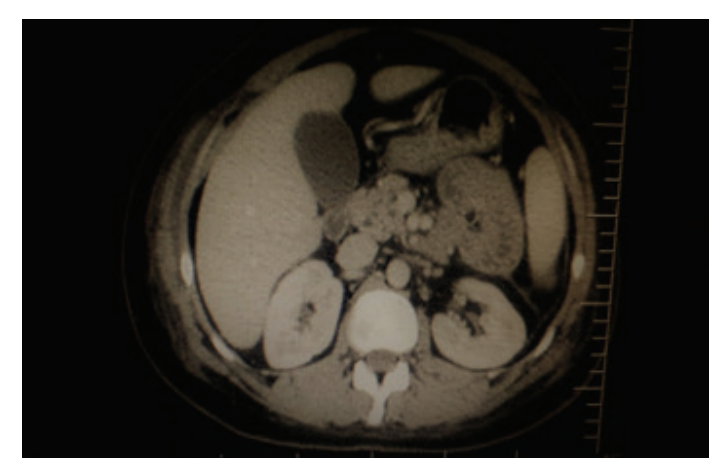

Resim 1. Batın tomografisinde safra kesesi duvar kalınlık artışı ve ödem

\section{TARTIŞMA}

Bruselloz sistemik semptomları nedeniyle, birçok hastalığın ayırıcı tanısında yer almaktadır. Bruselloz olgularında en sık rastlanan semptomlar, ateş yüksekliği, eklem ve kas ağrıları, artrit, karın ağrısı, baş ağrısı, halsizlik, yorgunluk, iştahsızlık, gastrointestinal semptomlar, kilo kaybı ve gece terlemesidir. Hastaların laboratuvar tetkiklerde hepatobiliyer enzim yükseklikleri ve kemik iliği süpresyonuna bağlı lökopeni, anemi ve trombositopeni görülebilir. ${ }^{5}$ Sunulan olgunun da sağ üst kadran ağrısı, ateş yüksekliği, üşüme ve titreme yakınmaları ile karaciğer enzim yüksekliği, lökopeni ve anemisi mevcuttu. Antibiyotik tedavisi ile laboratuvar tetkikleri normale döndü.

Kolesistit, safra kesesinin inflamatuar hastalığı olup tabloya safra kesesinde taş varlığı eşlik edebilir, ancak taşsız kolesistit de görülebilmektedir. Bruselloza bağlı safra kesesinin lenfatik ağ yoluyla bakteriyel kontaminasyonu enfeksiyonun sistemik yayılımı sırasında gelişebilir. ${ }^{6}$ Literatürde bruselloza bağlı kolesitit ilk olarak White ve ark. tarafından 1934'te bildirilmiştir. ${ }^{7}$ Sonraki yıllarda çeşitli ülkelerden benzer vaka bildirimleri olmuştur., ${ }^{4,8-10}$ Sunulan olgu da akut kolesistit tanısı ile takip edilmiş olan, tabloya safra kesesinde taşın eşlik etmediği bir olgudur.

Brusellozda, klinik belirti ve bulguların varlığında serum aglütinasyon testinin pozitif (Wright testi $\geq 1 / 160$ veya
Coombs'lu Wright testi $\geq 1 / 160$ ) olmasiyla tanıya gidilebilmektedir. ${ }^{5,6}$ Bruselloz tanısında serolojik tetkikler ön planda yardımcı olmaktadır, ancak negatiflik hastalığı ekarte ettirmez. Seronegatif vakalarda kültürde üremenin kesin tanıda yardımcı olduğu unutulmamalıdır. Brusellozda kesin tanı, çeşitli klinik örneklerden, özellikle kan ve kemik iliğinden Brucella türlerinin izole edilmesiyle konmaktadir. Sunulan olgunun da Rose Bengal testi pozitifti. Ancak Coombs'lu Wright testi 1/80 titrede pozitif olarak saptanması sonucu tanı kesinleștirilemedi ve serolojik tetkikler yanıltıcı oldu. Hastanın kan ve safra yollarına konan dren kültürlerinde B.melitensis üremesi ile hasta tanı aldı. Bu nedenle olgunun tanısında bir haftalık gecikme oldu.

Bizim olgumuzda olduğu gibi, kolesistitte yer alan Brucella türleri genellikle $B$. melitensis'tir. ${ }^{4,11,12}$ Ancak Morris ve arkadaşları B.suis'e bağlı bir kolesistit olgusunu bildirmiştir. $^{8}$ Brusella kolesistiti genellikle taşlı kolesistittir ${ }^{4}$, ancak literatürde akalküloz Brusella kolesistiti bildirimleri de mevcuttur. ${ }^{811,13}$ Literatürdeki akalküloz Brusella kolesistiti olgularının, genellikle immünsüpresif ve kronik nörolojik hastalığı olan vakalar olduğu bildirilmektedir. ${ }^{13}$ Bizim olgumuz da da akalküloz kolesistit tablosu mevcuttu ancak hastanın bilinen veya tespit edilen kronik bir hastalığı ve immünsupresyonu yoktu. Brusella kolesistiti tedavisinde, sıklıkla rifampisin ve doksisklin tedavisinin 6 haftaya tamamlandığ bildirilmektedir. ${ }^{6,10}$ Ancak tetrasiklin ve streptomisin tedavisini öneren literatür bilgiside mevcuttur. ${ }^{8}$ Bizim olgumuz da doksisiklin ve rifampisin kombinasyon tedavisi almıştır.

\section{SONUÇ}

Akut kolesistitlerin etiyolojisinde çoğunlukla safra taşı rol oynamasına rağmen, özellikle endemik bölgede yaşayan, mesleki maruziyet öyküsü olan kişilerde, brusellozun multisistem tutulumu akılda tutulmalı ve brusellozu dışlamak için serolojik tetkiklerin negatif olması yeterli olmayacağından kan kültürleri mutlaka alınmalıdır.

Tüm yazarlar çıkar çatışması olmadığını belirtmiştir. 
Sakarya Tip Dergisi 2019;9(4):702-705

\section{Kaynaklar}

1. Yüce A, Alp-Cavus S, Yapar N, Cakır N. Bruselloz: 55 olgunun değerlendirilmesi. Klimik Derg 2006;19(1):13-7.

2. Ozaras R, Celik AD, Demirel A. Acute hepatitis due to brucellosis in a laboratory technician. Eur J Intern Med 2004;15:264

3. Aziz S, Al-Anazi AR, Al-Aska AI. A review of gastrointestinal manifestations of Brucellosis. Saudi J Gastroenterol [serial online] 2005 [cited 2019 Apr 28];11:20-7.

4. Ali BI. Acute a Calcular Cholecystitis in a Patient with Brucellosis. Ann Clin Case Rep 2016;1(1):1101.

5. Alp E, Doğanay M. Bruselloz. In Topçu Wilke A, Söyletir G, Doğanay M. (eds) Enfeksiyon Hastalıkları ve Mikrobiyolojisi. Nobel Tip Kitabevi 2017 İstanbul 4.baskı.863-7.

6. Hakyemez IN, Tursun İ, Akkoyunlu Y. Kolesistit ve Pansitopeniyle Seyreden Bruselloz: Bir Olgu Sunumu ve Literatürün İncelenmesi. Klimik Derg 2011;24(2): 129-31.

7. White CS. Cholecystitis as a complication of brucellosis: report of a case. Medicine Annals D.C. $1934 ; 12: 60-2$.
8. Morris SJ, Greenwald RA, Turner RL, Tedesco FJ. Brucella-induced cholecystitis. Am J Gastroenterol 1979;71(5):481-4.

9. Fasquelle D, Charignon G, Rami M. Acute calcular cholecystitis in a patient with brucellosis. Eur J Clin Microbiol Infect Dis 1999;18(8):599-600.

10. Kanafani ZA, Sharara AI, Issa IA, Kanj SS. Acute calculous cholecystitis associated with brucellosis: a report of two cases and review of the literature. Scand J Infect Dis 2005;37(11 12):927-30.

11. Janbon F: La brucellose en. La Lettre de l'Infectiologue 1993;20:623-7.

12. Yildırım C, Akat EO, Taşbakan MI, Sipahi OR, Pullukçu H. Acute Cholecystitis and Granulomatous Hepatitis Caused by Brucella melitensis. Turkiye Klinikleri J Med Sci 2018;38(1):79-83.

13. Pourbagher MA, et al. Clinical pattern and abdominal sonographic findings in 251 cases of brucellosis in southern Turkey. AJR Am J Roentgenol 2006;187(2):191-4. 